\title{
Bio-optical characteristics of diatom and prymnesiophyte populations in the Labrador Sea
}

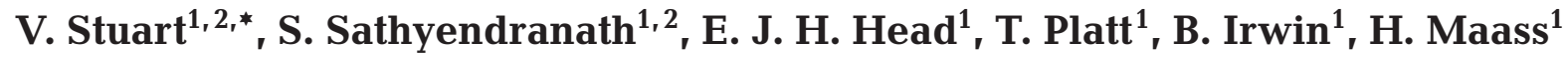 \\ ${ }^{1}$ Bedford Institute of Oceanography, PO Box 1006, Dartmouth, Nova Scotia B2Y 4A2, Canada \\ ${ }^{2}$ Oceanography Department, Dalhousie University, Halifax, Nova Scotia B3H 4J1, Canada
}

\begin{abstract}
During the spring of 1996, phytoplankton samples were collected along a transect from South Wolf Island (Labrador) to Cape Desolation (Greenland). Dense blooms of diatoms were found over the shelf near the coast of Labrador, whereas high concentrations of the colony-forming prymnesiophyte Phaeocystis pouchetii were found close to Greenland. Phytoplankton samples were separated into 2 major groups (diatoms or prymnesiophytes) on the basis of chlorophyll (chl) $\mathrm{chl} c_{3} / \mathrm{chl} \mathrm{a}$ ratios (determined by HPLC analysis), and the effects of species composition on the absorption and photosynthetic characteristics of these 2 high-latitude phytoplankton populations were studied. At all pigment concentrations and all wavelengths examined (apart from $623 \mathrm{~nm}$ ), the diatom population had a much lower absorption coefficient than the prymnesiophyte population; this was attributed to an increased pigment-packaging effect in the larger diatom cells. Varying proportions of photoprotective pigments also influenced the absorption characteristics of these populations. The low specific-absorption coefficient of the diatom population resulted in a higher maximum photosynthetic quantum yield relative to that of the prymnesiophyte population. The initial slope of the photosynthesis-irradiance (P-E) curve $\left(\alpha^{\mathrm{B}}\right)$ also appeared to be taxon-specific, with higher $\alpha^{\mathrm{B}}$ values being recorded for the smaller prymnesiophytes than for the larger diatom cells. The implications of speciesdependent variations in phytoplankton absorption coefficients for the retrieval of remotely-sensed chl $a$ are discussed.
\end{abstract}

KEY WORDS: Phytoplankton absorption · Bio-optical characteristics · Photosynthesis-irradiance curve $\cdot$ High latitudes $\cdot$ HPLC pigments

\section{INTRODUCTION}

The advent of a new generation of satellite oceancolour sensors has spurred interest in bio-optical characteristics of phytoplankton populations. These new, sophisticated sensors have a higher spectral resolution and better radiometric performance than the historic Coastal Zone Color Scanner (CZCS) (IOCCG 1998). Algorithms for retrieval of chlorophyll a (chl a) concentration from satellite-derived ocean-colour data are being developed and refined continually as new information becomes available. The algorithms are usually empirical in nature and are derived by statistical regression of water-leaving radiance against chlorophyll (O'Reilley et al. 1998). In contrast, theoretical or

*E-mail: vstuart@is.dal.ca semi-analytical models have also been developed to obtain a better understanding of the various factors that influence ocean colour (Morel \& Prieur 1977, Carder et al. 1999, Sathyendranath et al. 2000). The models express water-leaving radiance as a function of the inherent optical properties of the water column, i.e. the absorption and backscattering coefficients.

Specific-absorption coefficients of phytoplankton (absorption coefficients per unit concentration of chlorophyll) are known to vary regionally as well as seasonally (Bricaud \& Stramski 1990, Hoepffner \& Sathyendranath 1992, Lutz et al. 1996, Arrigo et al. 1998, Stuart et al. 1998, Sathyendranath et al. 1999) in response to changes in species composition, light history and nutrient conditions. Mitchell \& Holm-Hansen (1991) noted that specific absorption coefficients of phytoplankton from high-latitude areas were significantly 
lower than those from temperate waters. They attributed these low values to increased pigment-packaging effects, resulting from large cell size as well as high intracellular pigment concentrations (low-light adaptation). Any such variation in the bio-optical properties of phytoplankton assemblages can have a significant effect on the retrieval of chl a from remotely-sensed data. Thus, several studies report underestimation of the chl a concentration for certain phytoplankton populations in high-latitude areas, when standard algorithms developed for use with CZCS or SeaWiFS of data are used (Müller-Karger et al. 1990, Mitchell 1992, Sullivan et al. 1993, Arrigo et al. 1998). On the other hand, there are also reports that SeaWiFS algorithms overestimate pigment concentrations for certain phytoplankton populations in the Ross Sea by more than a factor of 2 (Arrigo et al. 1998). Because of these apparent inconsistencies, it is important that we improve our understanding of the bio-optical characteristics of phytoplankton in high-latitude areas and their impact on the retrieval of remotely-sensed chl a.

Computation of primary production is another application of remotely-sensed ocean-colour data. This computation requires specification of the photosynthetic characteristics of phytoplankton. The parameters of the photosynthesis-light curve $\left(\alpha^{\mathrm{B}}\right.$ and $\left.P_{\mathrm{m}}^{\mathrm{B}}\right)$ are highly variable, and are known to respond to changes in the environment such as variations in available light, temperature and nutrient conditions. There is a growing need to quantify the effect of environmental variables on the absorption and photosynthetic properties of natural phytoplankton populations, especially in the high-latitude areas. Environmental conditions in the Arctic are unique in that temperatures are low, nutrients show a strong seasonal signal, and the light regime varies greatly. Polar phytoplankton are known to exhibit extreme variability in their photosynthesis-irradiance (P-E) parameters which some authors have attributed to the wide range of environmental conditions (Harrison \& Platt 1986, Sakshaug \& Slagstad 1991, Figueiras et al. 1994). There is also evidence to suggest that photosynthetic responses may be taxonspecific (Platt et al. 1983) and may also vary with latitude (Harrison \& Platt 1986, Platt \& Sathyendranath 1995).

In this study, we examine the relationship between phytoplankton species-composition and changes in absorption and photosynthetic characteristics of 2 common phytoplankton groups from the Labrador Sea, in spring, to detect differences in optical para- meters in relation to environmental variables, cell size and pigment composition.

\section{MATERIALS AND METHODS}

Sampling procedures. Data were collected between 15 and 30 May 1996 during a cruise of the CCGS 'Hudson' to the Labrador Sea. Samples were collected at 13 stations along a transect from the edge of the ice-pack off South Wolf Island (Labrador) to Cape Desolation (Greenland) (Fig. 1). At each station, temperature and salinity profiles were recorded at $1 \mathrm{~m}$ intervals using a Seabird (Model SBE 25) sensor mounted on the frame of a sampling pump, which also carried a submersible fluorometer that monitored in situ chlorophyll fluorescence (Sea Tech Model 304). Seawater samples were collected with the pump at $10 \mathrm{~m}$ depth intervals within the upper $100 \mathrm{~m}$ of the water column for the determination of extracted chlorophyll and nutrient concentrations. For extracted chlorophyll determinations, $100 \mathrm{ml}$ water samples were filtered through GF/F filters at a vacuum differential of $<200 \mathrm{~mm} \mathrm{Hg}$ and immediately extracted overnight in $90 \%$ acetone. Chlorophyll concentration was measured using a Turner Designs fluorometer, according to the method of Holm-Hansen et al. (1965). Samples for nutrient determination were

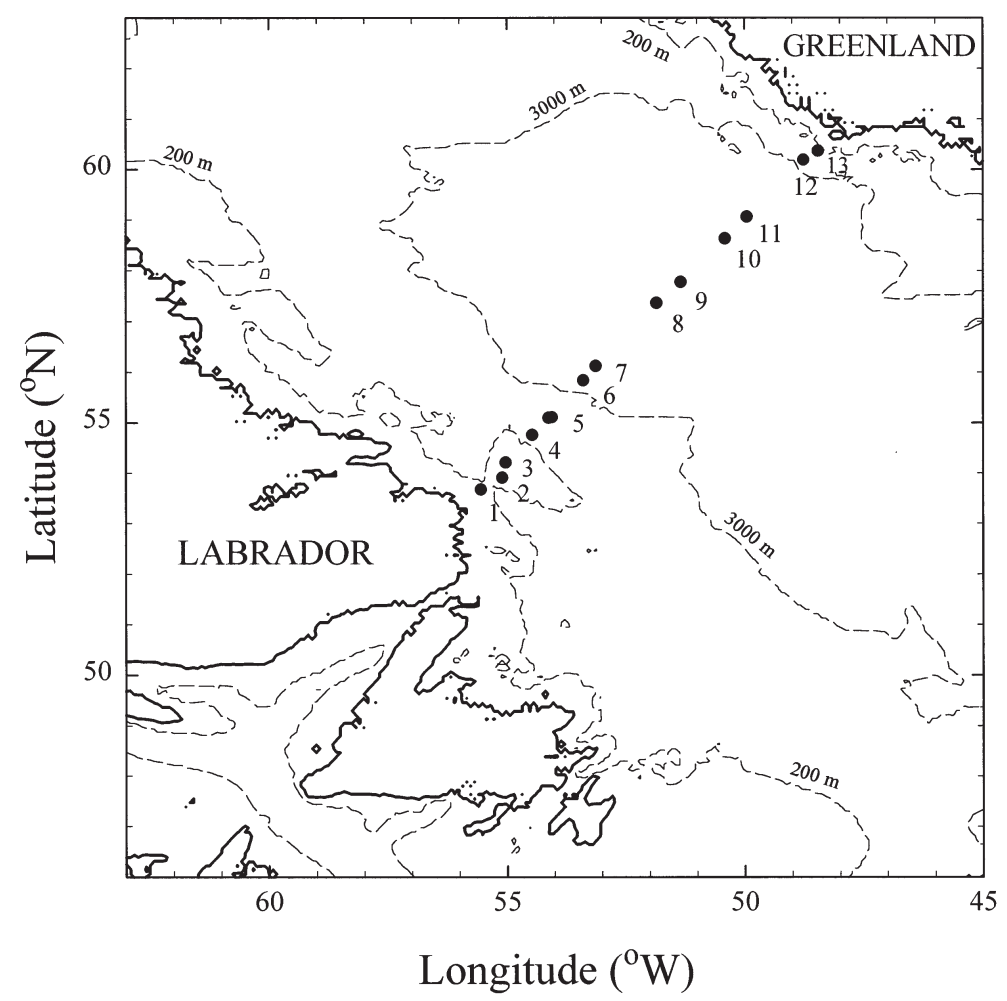

Fig. 1. Map of study area showing locations of sampling stations (1-13) along transect 
frozen at $-20^{\circ} \mathrm{C}$ for later analysis of nitrate, silicate and phosphate concentrations using an Alpkem RF-300 autoanalyzer. At each of the 13 stations, seawater samples were also collected from 3 depths between 10 and $50 \mathrm{~m}$ for the determination of absorption characteristics, pigment composition and parameters of the P-E curves.

Light absorption by phytoplankton. Particulate samples were collected on GF/F filters, and stored at $-70^{\circ} \mathrm{C}$ until processing using the filter technique of Yentsch (1962), as modified by Mitchell \& Kiefer $(1984,1988)$. Filters were placed on a drop of filtered seawater and the absorption of the total particulate material, $a_{p}(\lambda)$, relative to a blank filter saturated with seawater, was measured on a dual-beam Shimadzu UV-2101 PC scanning spectrophotometer equipped with an integrating sphere. Absorption by the detrital component, $a_{\mathrm{d}}(\lambda)$, of the sample was estimated according to the method of Kishino et al. (1985), with some minor modifications (see Stuart et al. 1998 and Sathyendranath et al. 1999 for details). Basically, phytoplankton pigments were extracted from the filters using a mixture of $90 \%$ acetone and dimethyl sulfoxide (DMSO) (6:4 vol:vol), and an exponential curve was fitted to the detrital absorption spectrum to correct for pigments which were not extracted.

Optical-density measurements were divided by the geometrical path length (volume filtered divided by clearance area of the filter) and multiplied by a factor of 2.3 (conversion factor for transforming decimal logarithms to natural logarithms) to obtain the absorption coefficient. The value of the absorption coefficient at $750 \mathrm{~nm}$ was subtracted from the values at all other wavelengths, as a rudimentary correction for errors arising from scattering by the phytoplankton cells. The measurements were corrected for path-length amplification arising from scattering by the filter, using the method of Hoepffner \& Sathyendranath $(1992,1993)$. Absorption by photosynthetic pigments, $a_{\mathrm{ph}}(\lambda)$, was then calculated as the difference between $a_{\mathrm{p}}(\lambda)$ and $a_{d}(\lambda)$. According to the manufacturer's specifications, the photometric accuracy of the spectrophotometer was \pm 0.002 for absorbance, and previous studies have found that the precision of absorption measurements ranged from 3 to $7 \%$ for different wavelengths (see Stuart et al. 1998). Pigment specific absorption coefficients of phytoplankton $\left[a_{\mathrm{ph}}^{*}(\lambda)\right]$ were calculated by dividing absorption by HPLC-determined chl a concentration.

Pigment analysis. Water samples for the detailed analysis of pigment composition were filtered onto $\mathrm{GF} / \mathrm{F}$ filters and stored at $-70^{\circ} \mathrm{C}$ until analyzed. At several stations, samples were also partitioned into 2 size fractions $(<3 \mu \mathrm{m}$ and total), using 2 seawater samples of the same volume. The first sample was filtered through a $3 \mu \mathrm{m}$ Nuclepore filter, and the filtrate was collected onto a GF/F filter to produce the $<3 \mu \mathrm{m}$ sizefraction. The second seawater sample was filtered directly onto a GF/F to give total pigment concentrations. Pigments were quantified with reverse-phase, high-performance liquid chromatography (HPLC) as described in Head \& Horne (1993). Frozen filters were homogenized in $1.5 \mathrm{ml} 90 \%$ acetone, centrifuged and diluted with $0.5 \mathrm{M}$ aqueous ammonium acetate at a ratio of 1:2 before injection. Peak identifications were made using standards for $\mathrm{chl} a_{1} b$ and $c$ (mixture of $c_{1}$ and $C_{2}$ ), 19-butanoyloxyfucoxanthin, fucoxanthin, 19hexanoyloxyfucoxanthin, diadinoxanthin, $\beta$-carotene, lutein and zeaxanthin. Standards of $\operatorname{chl} a, \operatorname{chl} b$ and $\beta$-carotene were obtained from Sigma Chemical Co., while other pigment standards were provided by Dr R. Bidigare.

Parameters of photosynthesis-light curve. Parameters of the photosynthesis-light curve were measured at each station by incubating samples for 2 to $3 \mathrm{~h}$ at in situ temperatures under 30 irradiance levels, ranging from 5 to $2000 \mu \mathrm{mol}$ quanta $\mathrm{m}^{-2} \mathrm{~s}^{-1}$, as described by Irwin et al. (1990). Primary production per hour, normalized to the biomass, B (HPLC-measured chl a concentration) was estimated by the ${ }^{14} \mathrm{C}$ method, and the results fitted with the equation of Platt et al. (1980) to determine the initial slope of the P-E curve $\left(\alpha^{\mathrm{B}}\right)$ and the assimilation number $\left(P_{\mathrm{m}}^{\mathrm{B}}\right)$.

The $\alpha^{\mathrm{B}}$ thus obtained is a non-spectral (broad-band) value, which is biased towards the red end of the spectrum because the emission spectrum of the tungstenhalogen lamp used in the experiments is rich in red wavelengths. To eliminate this bias, a correction factor was computed for $\alpha^{\mathrm{B}}$ using the shape of the phytoplankton absorption spectrum, as in Kyewalyanga et al. (1997). These authors demonstrated that this type of correction led to a significant decrease in the bias of the broad-band $\alpha^{\mathrm{B}}$ compared with the average $\alpha^{\mathrm{B}}$ determined from spectrally-resolved incubations.

\section{RESULTS AND DISCUSSION}

\section{Hydrography and fluorescence profiles}

Contour plots of temperature, salinity and nitrate profiles along the transect are shown in Fig. 2a,b,c. Temperature and salinity profiles were obtained from CTD data at $1 \mathrm{~m}$ intervals, whereas the nitrate profiles were obtained from analysis of pump samples, collected at $10 \mathrm{~m}$ intervals. These profiles display features that are consistent with the topography and circulation patterns. Hydrographic fronts occurred along the shelf break on both the Labrador and Greenland shelves. The water over these shelves was generally cooler 
(a) TEMPERATURE (CTD)

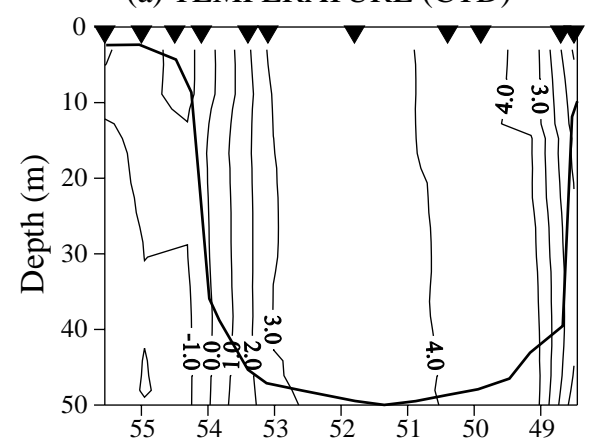

(c) NITRATE (PUMP)

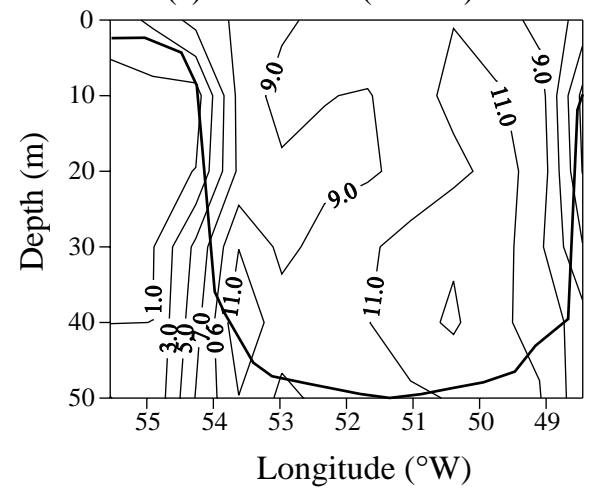

(b) SALINITY (CTD)

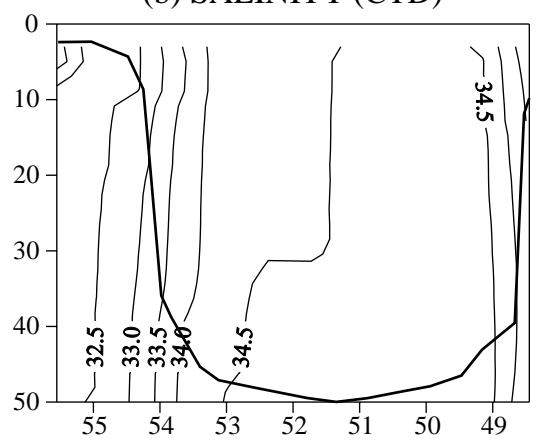

(d) RELATIVE FLUORESCENCE (CTD)

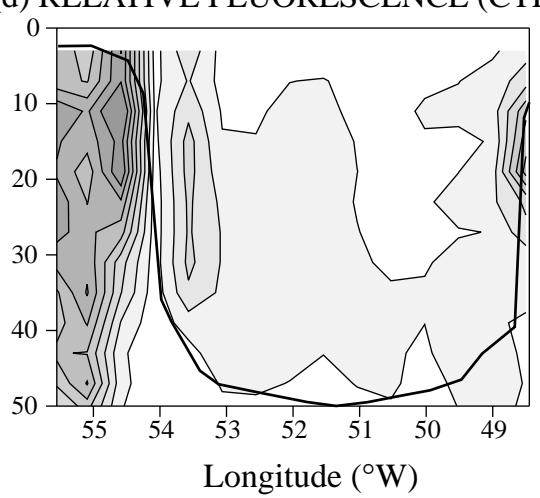

Fig. 2. Vertical profiles of (a) temperature $\left({ }^{\circ} \mathrm{C}\right)$, (b) salinity $(\%)$, (c) nitrate concentrations $(\mu \mathrm{M})$ and $(\mathrm{d})$ fluorescence (relative units) along transect from the coast of Labrador to coast of Greenland during May 1996. Location of sampling stations are indicated in (a). Temperature, salinity and fluorescence data were collected at $1 \mathrm{~m}$ intervals using CTD, whereas nitrate data was collected at $10 \mathrm{~m}$ intervals using sampling pump. Measurements were recorded down to a depth of $100 \mathrm{~m}$, but only data from top $50 \mathrm{~m}$ are shown (CTD contours were started at $3 \mathrm{~m}$ because of instrument fluctuations in top few meters). Heavy line overlay shows bathymetry along transect, deepest point being $>3000 \mathrm{~m}$ (not drawn to scale). Extracted chlorophyll values ranged from $18 \mathrm{mg}$ $\mathrm{m}^{-3}\left(10 \mathrm{~m}, 55^{\circ} \mathrm{W}\right)$ to $<0.5 \mathrm{mg} \mathrm{m}^{-3}$ in central portion of the transect at depth of $50 \mathrm{~m}$. High fluorescence patch at $48.5^{\circ} \mathrm{W}$ $(10 \mathrm{~m})$ coincided with extracted chlorophyll concentrations of $5.5 \mathrm{mg} \mathrm{m}^{-3}$

( -0.8 to $-1.4^{\circ} \mathrm{C}$ ) and less saline (32.2 to $32.7 \%$ ) than the water in the central part of the transect, which may be attributable to melting sea-ice and the influence of cool, fresh water from the Baffin Island and East Greenland Currents, the central region being more influenced by the North Atlantic water (see Head et al. 2000). In general, ice covers the entire Labrador Shelf until early April, when it starts to melt rapidly. Cool, fresh water extended over the eastern Labrador shelf to the shelf break (around $54^{\circ} \mathrm{W}$ ), and was confined to a narrow band corresponding to the much narrower shelf along the coast of Greenland. All profiles in Fig. 2 indicate that there was no significant stratification of the water column down to a depth of $50 \mathrm{~m}$.

Highest nitrate concentrations (up to $13.5 \mu \mathrm{M}$ ) were associated with the warmer $\left(3\right.$ to $\left.4^{\circ} \mathrm{C}\right)$, more saline waters (34.4 to $34.7 \%$ ) towards the eastern section of the transect, while low, sometimes undetectable, levels of nitrate were found over the Labrador shelf. These low nitrate concentrations coincided with extremely high levels of chlorophyll fluorescence (Fig. 2d), indicative of a phytoplankton bloom, suggesting that the bloom had significantly depleted available nutrients. This is clearly observed in Fig. 3, where extracted chlorophyll concentrations and total nitrate concentrations, integrated down to a depth of $50 \mathrm{~m}$, have been plotted against longitude. Integrated nitrate concentrations $\left(N_{\text {int }}\right)$ showed a significant negative relationship with integrated chlorophyll concentrations $\left(C h l_{\text {int }}\right)$ for these stations $\left(N_{\text {int }}=562.29-0.8707 C h l_{\text {int, }} \mathrm{n}=11\right.$, $\left.\mathrm{r}^{2}=0.88\right)$. Extracted chlorophyll concentrations within the bloom reached $18 \mathrm{mg} \mathrm{m}^{-3}$. A patch of relatively high fluorescence, coinciding with extracted chlorophyll measurements of up to $5.5 \mathrm{mg} \mathrm{m}^{-3}$, was observed near the coast of Greenland, while low fluorescence levels were recorded in the central portion of the transect, coinciding with extracted near-surface concentrations of $<2 \mathrm{mg} \mathrm{m}^{-3}$. Although estimates of extracted chlorophyll concentrations co-varied with measurements of fluorescence from the CTD rosette, the two 


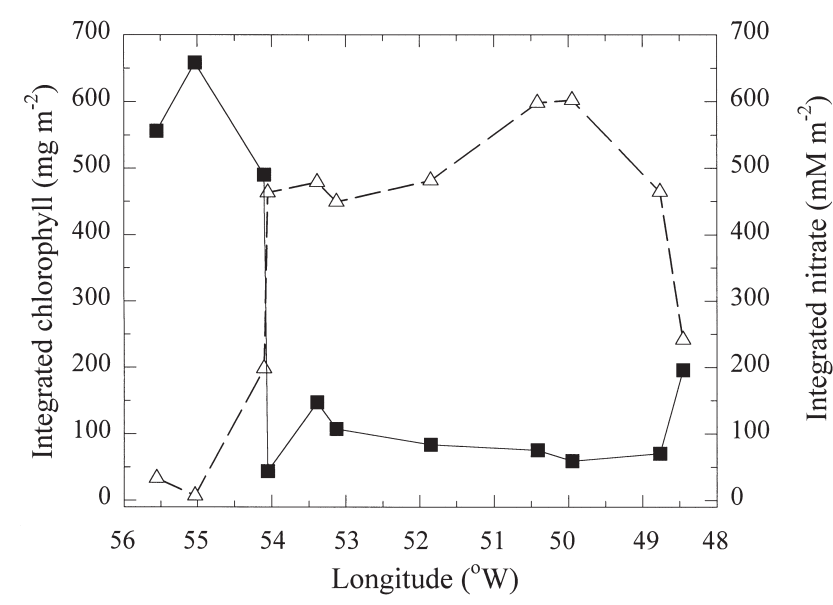

Fig. 3. Extracted chlorophyll concentrations (ם) and total nitrate concentrations $(\Delta)$ for each sampling station, integrated down to a depth of $50 \mathrm{~m}$

were not well correlated, perhaps because of variations in fluorescence yield between different phytoplankton populations (see also Head et al. 2000). For this reason, the fluorescence measurements in Fig. $2 d$ are presented in relative units.

The hydrographic features discussed above are similar to those of previous studies conducted in the Labrador Sea area during the May/June period. Typically, hydrographic fronts are associated with the shelf break on both the Labrador and Greenland shelves, and algal blooms are frequently associated with these fronts (e.g. Labrador shelf front: Cabal et al. 1997, Labrador and Greenland shelf fronts: Head et al. 2000).

\section{Pigment composition}

HPLC analysis revealed very high concentrations of chl a (up to $14 \mathrm{mg} \mathrm{m}^{-3}$ ) over the Labrador shelf (Stns 1 to 4), and moderately high levels of chl a (up to $3.4 \mathrm{mg}$ $\mathrm{m}^{-3}$ ) near the coast of Greenland (Stn 13), which is in agreement with the fluorescence profiles (Fig. 2d). In the middle section of the transect, chl a concentrations were lower, in the range of 0.5 to $2 \mathrm{mg} \mathrm{m}^{-3}$. Detailed pigment analysis suggested that diatoms dominated the phytoplankton assemblage near the coast of Labrador, as evidenced by the high proportions of fucoxanthin and chl $C_{1+2}$, and the presence of diadinoxanthin (Fig. 4). Microscopic analysis of phytoplankton samples confirmed the abundance of diatoms, and the dominant species were identified as Thalassiosira sp., Chaetoceros sp. and Fragilaria oceania. Size fractionation indicated that most of the chlorophyll at these stations came from cells $>3 \mu \mathrm{m}$.
Large aggregations of gelatinous Phaeocystis colonies were observable with the naked eye in samples collected by bucket from the sea surface near the coast of Greenland (Stn 13). Microscopic analysis at the time of sampling confirmed them to be P. pouchetii (Haptophyta, Prymnesiophyceae). HPLC analysis of samples taken from the bloom stations revealed relatively high levels of chl $c_{3}$, which has been used as a marker for a majority of bloom-forming prymnesiophytes (see Johnsen \& Sakshaug 1993, Jeffrey et al. 1997). It should be noted here that these $P$. pouchetii samples contained no 19'-hexanoyloxyfucoxanthin or 19'-butanoyloxyfucoxanthin, pigments which are commonly found in Phaeocystis sp. from Antarctic waters (Buma et al. 1991, Arrigo et al. 1998). Samples from the middle section of the transect, however, did contain these 2 pigments, as well as chl $c_{3}$, chl $b$, chl $c_{1+2}$ and diadinoxanthin (Fig. 4), suggesting the presence of other prymnesiophyte species, for example, Emiliania huxleyi (characterized by chl $C_{3}$ and 19'-hexanoyloxyfucoxanthin), as well as chlorophytes (characterized by $\mathrm{chl} b$ ). Unfortunately, phytoplankton samples were not collected specifically for microscopic analysis from these stations, so the identification of these algal classes could not be confirmed. Head et al. (2000) reported that $P$. pouchetii, Chaetoceros spp. and Thalassiosira spp. were the most abundant species in this region during the spring of 1997, similar to the 1996 results presented here.

Size-fractionation revealed that $\sim 40 \%$ of the $\operatorname{chl} a$ from the Phaeocystis pouchetii bloom occurred in the $<3 \mu \mathrm{m}$ size fraction, compared to only $3.4 \%$ for the

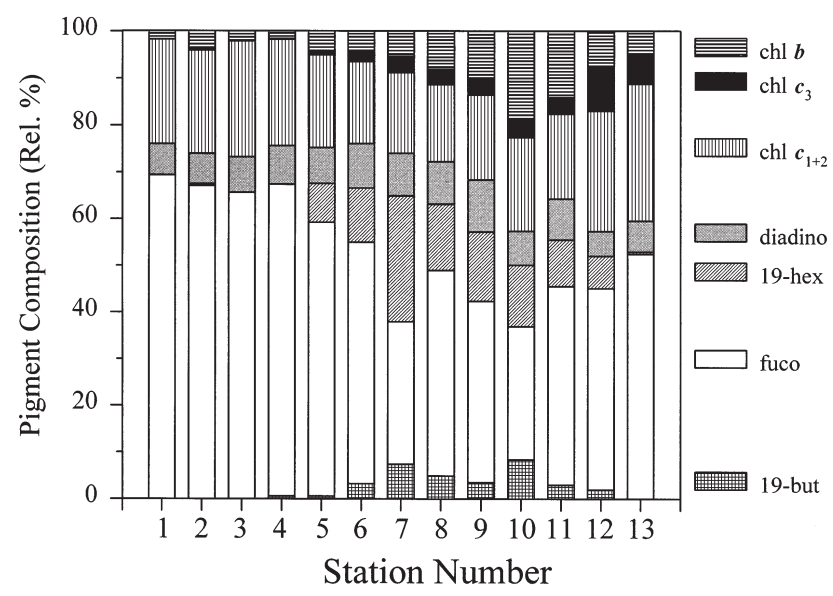

Fig. 4. Relative proportion of different accessory pigments (expressed as percentage of total accessory pigments) at each sampling station along transect (average of all samples from each sampling station). 19-but $=19$ '-butanoyloxyfucoxanthin; fuco $=$ fucoxanthin; 19-hex $=19^{\prime}$-hexanoyloxyfucoxanthin; diadino $=$ diadinoxanthin $;$ chl $c_{1+2}=$ chlorophyll $c_{1+2} ;$ chl $c_{3}=$ chlorophyll $c_{3} ;$ chl $b=$ chlorophyll $b$ 
diatom samples (excluding Stn 5 outlier, see following paragraph). In the middle of the transect, 40 to $80 \%$ of the chl a occurred in the smaller $(<3 \mu \mathrm{m})$ size fraction. The aggregations of $P$. pouchetii colonies observed floating on the surface of the water (up to several $\mathrm{mm}$ in diameter) were disrupted by the sampling pump during collection, so the measurements are somewhat biased towards smaller individual cells at the expense of larger colonies. However, results from samples collected the following year (May 1997) indicated that the sampling pump did not cause cellular damage to the $P$. pouchetii cells and that disruption of colonies by the pump had little effect on the absorption properties of the $P$. pouchetii-dominated colonies (see Appendix 1).

Phytoplankton samples were separated into 2 groups, based on the ratio of chl $c_{3}$ to $\mathrm{chl}$ a. We have assumed that samples which had chl $C_{3} / \mathrm{chl}$ a ratios of $<0.02$ contained mostly larger diatoms (many of these samples had undetectable levels of chl $c_{3}$ ), while samples with $\mathrm{chl} C_{3} / \mathrm{chl}$ a ratios greater than 0.02 were composed predominantly of small prymnesiophytes. This scheme appeared to work well for most samples from the study site, apart from 1 sample collected at Stn 5, which was composed of small chlorophytes and prymnesiophytes $(80 \%$ of the chl a from this sample was in the $<3 \mu \mathrm{m}$ size fraction). This sample, which had relatively high levels of chl $b$ and 19'-hexanoyloxyfucoxanthin, was grouped with the diatoms because the $\mathrm{chl} c_{3} / \mathrm{chl}$ a ratio was less than $0.02\left(\mathrm{chl} c_{3} / \mathrm{chl} \mathrm{a}=\right.$ 0.015), even though it might fit better with the smaller prymnesiophytes. Clearly some stations contained a mixture of diatoms and prymnesiophytes, as indicated by the presence of a small amount of chl $c_{3}$ in the presumed 'diatom' population (see Table 1).

Absorption and photosynthetic characteristics of the 2 dominant phytoplankton assemblages (diatoms and

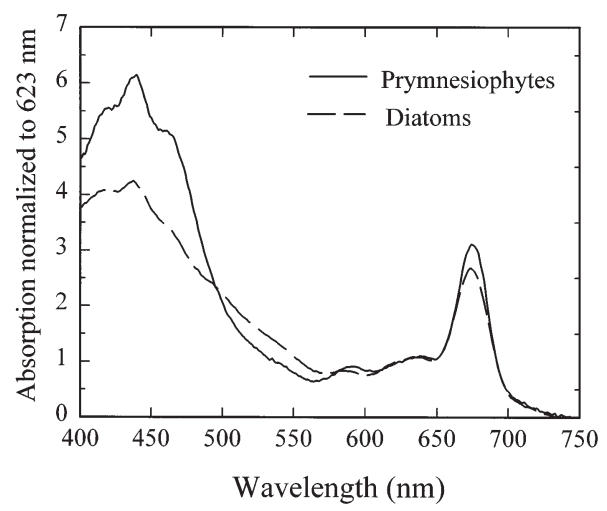

Fig. 5. Average absorption spectra for diatom- and prymnesiophyte-dominated populations normalized to absorption at $623 \mathrm{~nm}$ ( $\mathrm{n}=16$ for prymnesiophytes, 12 for diatoms). Populations were separated on the basis of $\mathrm{chl} c_{3} / \mathrm{chl}$ a ratios (see 'Results' for details) prymnesiophytes) were examined separately on this basis, and the results are reported below.

\section{Light absorption by phytoplankton}

\section{Absorption spectra}

To examine differences in the shapes of the absorption spectra of the 2 dominant phytoplankton assemblages, the average absorption spectrum of each group was normalized to $623 \mathrm{~nm}$, since this region of the spectrum is only weakly affected by variations caused by the packaging effect and changes in pigment composition (Stuart et al. 1998). The prymnesiophyte population had higher absorption coefficients than the diatom population in the blue region of the spectrum $(\sim 440 \mathrm{~nm})$, with somewhat smaller differences in the red region of the spectrum (676 nm) (Fig. 5). Note that the differences in magnitude of the absorption spectra are relative, since the spectra have been normalized to $623 \mathrm{~nm}$.

The diatom population showed an enhanced absorption in the green part of the spectrum, between 500 and $575 \mathrm{~nm}$, which can be attributed to absorption by fucoxanthin. Indeed, fucoxanthin/chl a ratios were noticeably higher for the diatom population than for the prymnesiophyte population (Table 1). Taxonomic differences in absorption in this part of the spectrum are important for remote-sensing applications, since standard SeaWiFS algorithms use the wavebands 490 and $555 \mathrm{~nm}$ to estimate chl a concentrations (O'Reilley et al. 1998). The ratio of $a_{\mathrm{ph}}(490) / a_{\mathrm{ph}}(555)$ was found to be significantly higher $(\mathrm{p}=0.000,2$ sample $t$-test) for the prymnesiophyte population than for the diatom population (Table 1). Differences between the 2 phytoplankton populations were also evident in comparisons of other absorption ratios, for example, the mean ratios of $a_{\mathrm{ph}}(443) / a_{\mathrm{ph}}(550)$ and $a_{\mathrm{ph}}(443) / a_{\mathrm{ph}}(676)$ were also significantly lower for the diatom-dominated population than for the prymnesiophyte-rich population (Table 1). Similarly, Arrigo et al. (1998) noted lower blue:green ratios for diatoms than for Phaeocystis spp. assemblages in Antarctic waters, although in their study the differences were not as pronounced, probably because the diatoms in their study were relatively small $\left(30 \mu \mathrm{m}^{3}\right)$.

\section{Absorption coefficients}

Specific-absorption coefficients at 443 and $676 \mathrm{~nm}$ $\left[a_{\mathrm{ph}}^{*}(443)\right.$ and $\left.a_{\mathrm{ph}}^{*}(676)\right]$ were significantly lower $(\mathrm{p}=$ 0.000 ) for the diatom population than for the prymnesiophytes (Table 1). The values reported in Table 1 are 
normalized to HPLC-derived chl a measurements, excluding phaeopigments. These values are somewhat lower when absorption is normalized to HPLC chl a plus phaeopigments, or to fluorometrically derived chl a (see also Stuart et al. 1998). However, the differences between the 2 major population groups remain significant even with these other normalizations. Mean values of $a_{\mathrm{ph}}^{*}(443)$ for the diatom population $\left(0.027 \mathrm{~m}^{2}[\mathrm{mg}\right.$ $\mathrm{chl} \mathrm{a]^{-1 }}$ ) are similar to those recorded for phytoplankton populations from high-latitude environments (Mitchell \& Holm-Hansen 1991), whereas values for the prymnesiophyte population fall within the range of values reported for phytoplankton from low- and mid-latitudes (Bricaud \& Stramski 1990, Hoepffner \& Sathyendranath 1992). Our $a_{\mathrm{ph}}^{*}$ values for prymnesiophytes also fall within the range of values reported by Cota et al. (1994) for a Phaeocystis spp. bloom in the Greenland Sea, and by Moisan \& Mitchell (1999) for $P$. antarctica grown under different light regimes.

The relationship between phytoplankton absorption and chl a concentration can be described by a Michaelis-Menten equation of the form:

$$
a_{\mathrm{ph}}(\lambda)=\frac{a_{\mathrm{m}} a_{\mathrm{m}}^{*} C}{a_{\mathrm{m}}+a_{\mathrm{m}}^{*} C}
$$

where $a_{\mathrm{m}}$ is the asymptotic maximum value of the absorption coefficient, $a_{\mathrm{m}}^{*}$ is the initial slope of the curve near the origin (maximum specific-absorption coefficient) and $C$ is the HPLC-derived chl a concentration (see Lutz et al. 1996, Stuart et al. 1998,
Sathyendranath et al. 2000). Parameters for this function are presented in Table 2 for various wavelengths used in standard remote-sensing algorithms $(443,490,550,555 \mathrm{~nm})$ as well as for $623 \mathrm{~nm}$. At a given chlorophyll concentration, absorption by the prymnesiophytes was substantially higher than that by the diatoms at all wavelengths examined, apart from the waveband at $623 \mathrm{~nm}$ (Fig. 6). At $623 \mathrm{~nm}$, differences in absorption coefficients between the 2 phytoplankton populations were less apparent (Fig. 6b), probably because of the absence of any significant flattening effect at this wavelength (see also Geider \& Osborne 1987, Stuart et al 1998). In Fig. 6b, a single function was used to describe the relationship between pigment concentration and phytoplankton absorption at $623 \mathrm{~nm}$, but the coefficients for 2 separate functions (diatom and prymnesiophyte populations) are given in Table 2.

The observed differences in absorption coefficients between the 2 phytoplankton populations can be attributed to variations in the package effect and to differences in pigment composition. Changes in the package effect are known to be caused by 2 factors: changes in cell size and variations in intracellular pigment concentration, frequently associated with photoadaptative responses (Duysens 1956, Morel \& Bricaud 1981, Kirk 1994). Large diatom cells have a much greater pigment-packaging effect (and thus a lower absorption coefficient) than the smaller prymnesiophyte cells. The lower absorption coefficients of the diatom population might also be due partly to increased intracellular pigment concentrations resulting from photoadaptation to the low light levels in highlatitude areas (see Robinson 1992, Arrigo et al. 1993). An increase in intracellular pigment concentration would act to augment the packaging effect and thus reduce specific-absorption coefficients (Morel \& Bricaud 1981, Mitchell \& Kiefer 1988). In addition, in areas of high chlorophyll concentration, such as in the dense algal blooms over the shelf breaks, light would be strongly attenuated, further reducing ambient light levels and resulting in photoadaptation of the cells within the bloom. Indeed, cells within the intensive diatom and prymnesiophyte blooms at either end of the transect had relatively low levels of diadinoxanthin (a photoprotective pigment) compared with phytoplankton assemblages from the middle section of the transect (Fig. 7), suggesting that ambient light levels were lower in the bloom areas. 
Table 2. Parameters of Michaelis-Menten type function (see 'Results' for details) relating absorption to HPLC-derived chl a concentration, for diatomand prymnesiophyte-dominated phytoplankton assemblages in Labrador Sea in May 1996 ( $\mathrm{n}=16$ for prymnesiophytes; $\mathrm{n}=12$ for diatoms). Values are given for each wavelength used in standard CZCS (443 and $550 \mathrm{~nm}$ ) and SeaWiFS (490 and $555 \mathrm{~nm}$ ) algorithms as well as for $623 \mathrm{~nm} ; a_{\mathrm{m}}\left(\mathrm{m}^{-1}\right)=$ asymptotic maximum value of $a_{\mathrm{ph} i} a_{\mathrm{m}}^{*}\left(\mathrm{~m}^{2}[\mathrm{mg} \mathrm{chl} \mathrm{a}]^{-1}\right)=$ initial slope near origin (maximum specific-absorption coefficient)

\begin{tabular}{|lcccccc}
\hline \multicolumn{2}{l}{$\begin{array}{l}\text { Wavelength } \\
(\lambda)(\mathrm{mm})\end{array}$} & $a_{\mathrm{m}}$ & $\begin{array}{c}\text { Diatoms } \\
a_{\mathrm{m}}^{*}\end{array}$ & $\mathrm{r}^{2}$ & \multicolumn{3}{c}{ Prymnesiophytes } \\
\hline 443 & 0.7641 & 0.0218 & 0.91 & 0.3561 & 0.0802 & 0.96 \\
490 & 0.3861 & 0.0130 & 0.89 & 0.1353 & 0.0572 & 0.82 \\
550 & 0.2018 & 0.0063 & 0.94 & 0.0577 & 0.0132 & 0.89 \\
555 & 0.1831 & 0.0057 & 0.94 & 0.0548 & 0.0112 & 0.91 \\
623 & 0.1763 & 0.0059 & 0.92 & 0.0932 & 0.0094 & 0.95 \\
\hline
\end{tabular}

Single function for diatoms and prymnesiophytes combined:

$\begin{array}{llll}623 & 0.0970 & 0.0082 & 0.94\end{array}$ the state of photoadaptation of the cells. Cells adapted to high light levels will have relatively high levels of diadinoxanthin, and thus an enhanced absorption around $490 \mathrm{~nm}$, resulting in lower blue/green absorption ratios. This is also evident in the Labrador Sea data, where prymnesiophyte-dominated samples from the middle section of the transect displayed the lowest blue/green absorption ratios in conjunction with relatively high levels of NPCs (see Figs. 7 \& 8). Samples taken from within the dense Phaeocystis pouchetii bloom, on the other hand, contained very low concentrations of photoprotective carotenoids, resulting in higher blue/ green absorption ratios.
Influence of photoprotective pigments

Variations in phytoplankton absorption are also known to be influenced by the relative proportion of photoprotective or non-photosynthetic carotenoids (NPC) (Bricaud et al. 1995). In addition, Culver \& Perry (1999) demonstrated that the photoprotective absorption coefficient of phytoplankton varies directly with irradiance, and can account for much of the variability in the spectral shape of the total phytoplankton absorption coefficient. In our study, the ratio of NPC/chl a was directly related to the blue/green ratio of phytoplankton absorption $\left[a_{\mathrm{ph}}(443) / a_{\mathrm{ph}}(490)\right]$ (Fig. 8). We have assumed that diadinoxanthin, diatoxanthin, alloxanthin, $\beta$-carotene and zeaxanthin are NPCs, as in Bricaud et al. (1995). This plot clearly shows a pigment effect, with the absorption ratio decreasing with increase in NPC. Some of the scatter around the regression line may reflect a size (flattening) effect. Large cells, with a greater flattening effect, would be expected to have a smaller absorption ratio for a given pigment composition than smaller cells with the same pigment composition. Indeed, this would appear to be the case for most of the samples from the study site. In particular, the large diatom samples all lie below the regression line. Stn 5, which was included with the larger diatoms because of its relatively low $\mathrm{chl} c_{3} / \mathrm{chl} a$ ratio, was actually comprised of $80 \%$ small cells, and lies well above the regression line.

High-light acclimated cells can have up to 3 times higher concentrations of photoprotective carotenoids (such as diadinoxanthin) relative to levels in low-light acclimated cells (Johnsen \& Sakshaug 1996). Since diadinoxanthin has an in vivo absorption maximum around $490 \mathrm{~nm}$, changes in blue/green absorption ratios can also reflect changes in pigment composition and
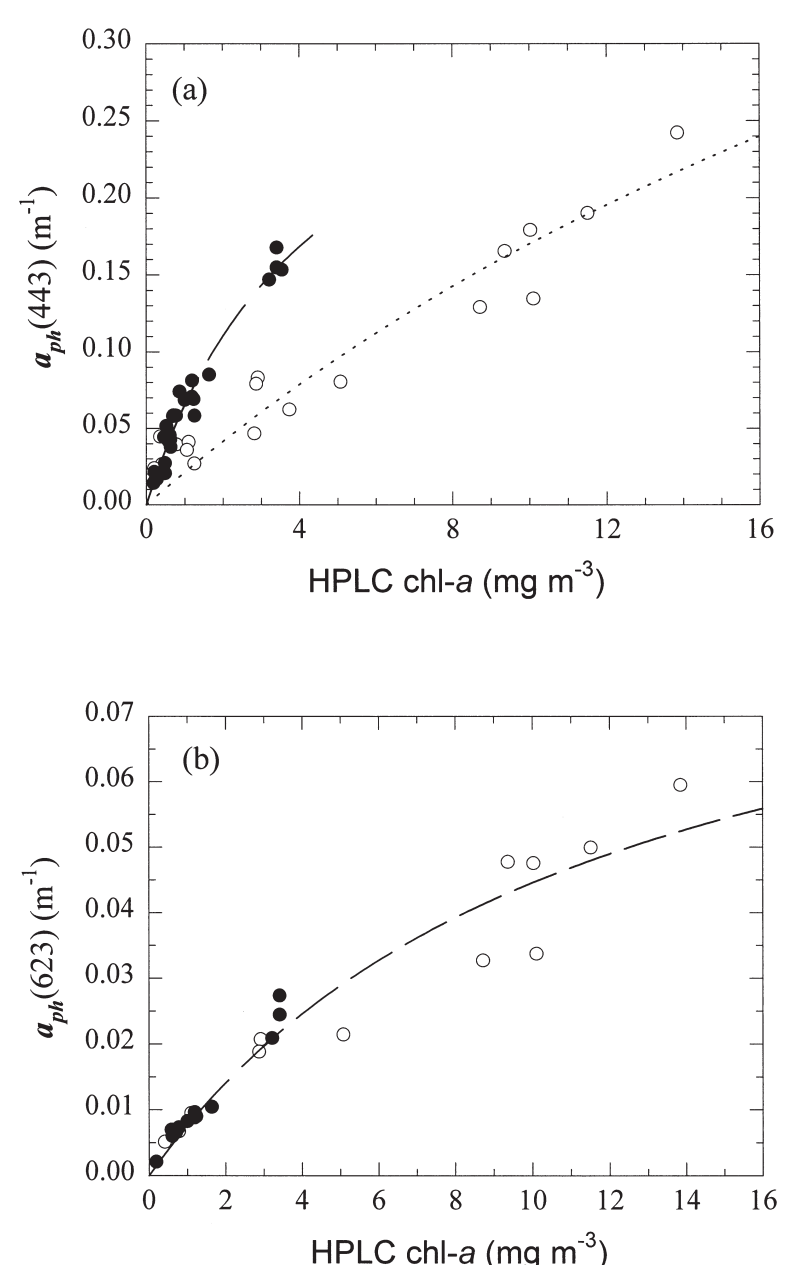

Fig. 6. Absorption $\left(\mathrm{m}^{-1}\right)$ by diatoms $(0)$ and prymnesiophytes (•) at (a) $443 \mathrm{~nm}$ and (b) $623 \mathrm{~nm}$, plotted as function of HPLCderived chl a concentration (see Table 2 for parameters of function). Populations were separated on basis of $\mathrm{chl} c_{3} / \mathrm{chl} a$ ratios (see 'Results' for details) 


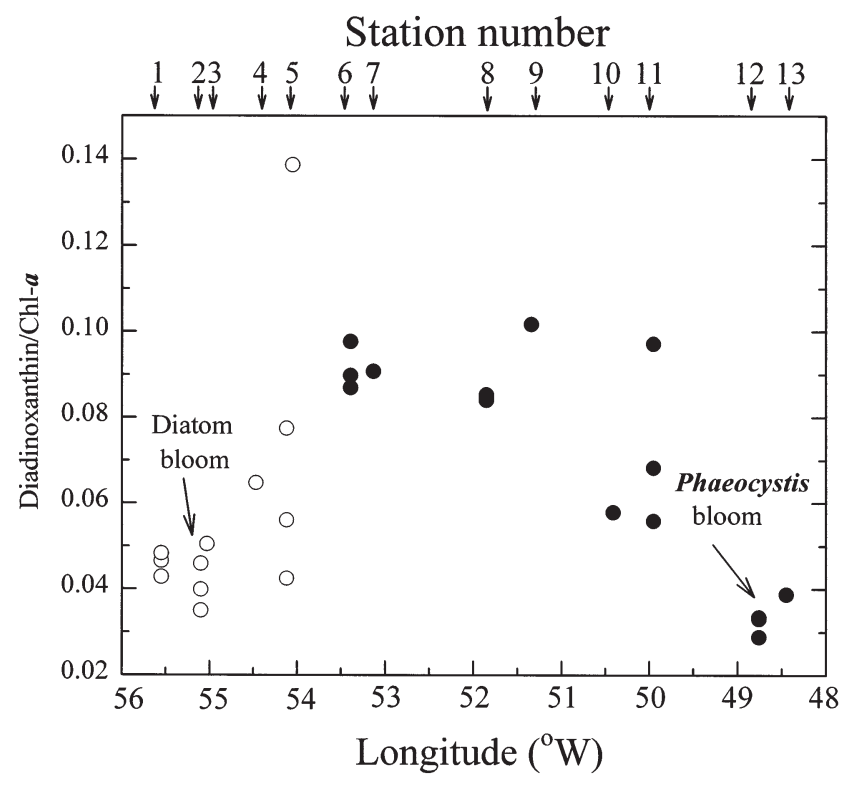

Fig. 7. Ratio of diadinoxanthin to chl a for phytoplankton populations dominated by diatoms $(\mathrm{O})$ and prymnesiophytes ( $)$ at sampling stations along transect from coast of Labrador to coast of Greenland

\section{Photosynthetic parameters}

Measured values of the initial slope of the P-E curve $\left(\alpha^{\mathrm{B}}\right)$ ranged from 0.006 to $0.047 \mathrm{mg} \mathrm{C}(\mathrm{mg} \mathrm{chl})^{-1} \mathrm{~h}^{-1}$ ( $\mu \mathrm{mol}$ quanta $\left.\mathrm{m}^{-2} \mathrm{~s}^{-1}\right)^{-1}$ which closely approximates the range reported by Sakshaug \& Slagstad (1991) for polar phytoplankton species $(0.007$ to $0.040 \mathrm{mg} \mathrm{C}$ [mg $\mathrm{chl}]^{-1} \mathrm{~h}^{-1}\left[\mu \mathrm{mol} \text { quanta } \mathrm{m}^{-2} \mathrm{~s}^{-1}\right]^{-1}$ ). One prymnesiophyte sample from $50 \mathrm{~m}$ was excluded from this analysis since it had an abnormally high $\alpha^{\mathrm{B}}$ value. The mean value of $\alpha^{\mathrm{B}}$ for the prymnesiophyte population was significantly higher $(\mathrm{p}<0.05)$ than that of the diatom population (Table 1), suggesting that photosynthetic rate might be size- or taxon-specific. Several other studies have reported significantly higher values of $\alpha^{\mathrm{B}}$ for smaller size fractions than for larger phytoplankton assemblages (Platt et al. 1983, Joint \& Pomroy 1986), and Cota et al. (1994) noted unusually high values of $\alpha^{\mathrm{B}}$ (0.028 to $0.097 \mathrm{mg} \mathrm{C}$ [mg chl a $]^{-1} \mathrm{~h}^{-1}$ [ $\mathrm{mmol}$ quanta $\mathrm{m}^{-2}$ $\left.\mathrm{s}^{-1}\right]^{-1}$ ) for a Phaeocystis spp. bloom in the Greenland Sea in early spring.

In the present study, $\alpha^{\mathrm{B}}$ was related in a linear fashion to the specific-absorption coefficient of phytoplankton at $676 \mathrm{~nm}$ (Fig. 9a), as well as to environmental variables such as nitrate concentration, temperature and salinity (Fig. 9b-d). These latter correlations imply that factors other than phytoplankton population structure may also have contributed to changes in $\alpha^{\mathrm{B}}$. Indeed, linear regression analysis indicated that some
$42 \%$ of the variance in $\alpha^{\mathrm{B}}$ could be explained by variations in temperature and depth alone, although covariance of factors should not be ruled out; for example, diatoms were confined predominantly to low-temperature, low-salinity, low-nutrient environments. It should be noted that these results are based on a relatively small number of observations at one point in time, and that the observed relationships might be affected by temporal and seasonal variations.

Unlike $\alpha^{\mathrm{B}}$, the light-saturated rate of chlorophyllnormalized photosynthesis $\left(P_{\mathrm{m}}^{\mathrm{B}}\right)$ showed no significant relationship with cell size, depth, temperature or nutrient concentrations. Furthermore, $P_{\mathrm{m}}^{\mathrm{B}}$ was not correlated with either absorption characteristics or pigment composition, and there were no significant differences ( $\mathrm{p}=0.83$ ) between the mean $P_{\mathrm{m}}^{\mathrm{B}}$ for the diatom population and the prymnesiophyte population (Table 1). This is in contrast with the results of Platt et al. (1993), who found that temperature and depth alone could account for some $65 \%$ of the variance in $P_{\mathrm{m}}^{\mathrm{B}}$ for phytoplankton samples from the Celtic Sea during late spring. In their study, however, variations in temperature, depth and nitrate could not explain significant proportions of the variance in $\alpha^{\mathrm{B}}$, for unfractionated samples.

Values for $P_{\mathrm{m}}^{\mathrm{B}}$ were lower than those from warmer waters (Platt \& Jassby 1976, Côté \& Platt 1983, Sathyendranath et al. 1999), ranging from 1.14 to $5.45 \mathrm{mg} \mathrm{C}$ (mg chl a $)^{-1} \mathrm{~h}^{-1}$, but comparable to assimilation numbers for phytoplankton populations from similar latitudes, in spring and summer (Neori \& Holm-Hansen

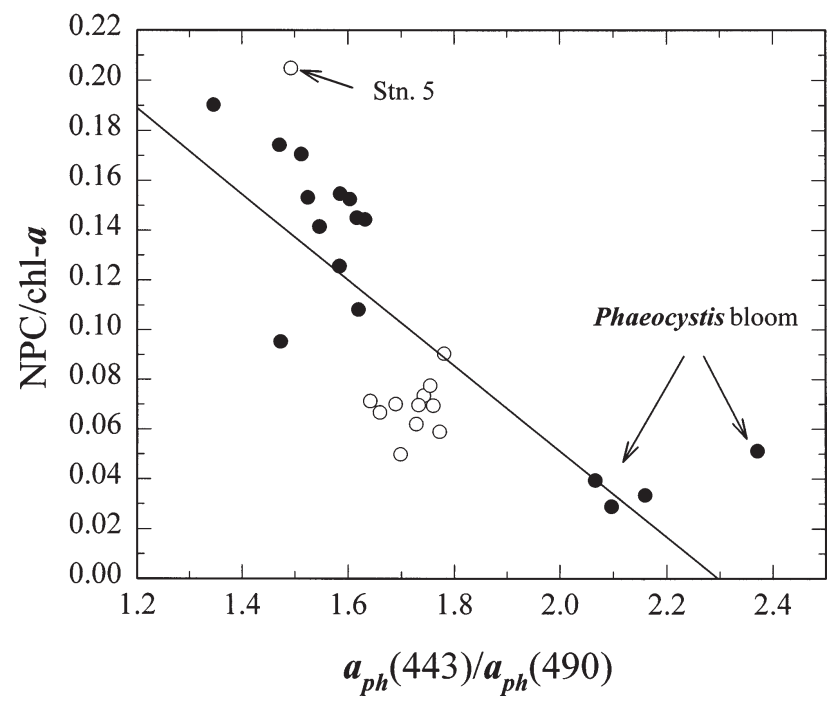

Fig. 8. Ratio of total non-photosynthetic carotenoids (NPC) to chl a plotted as function of ratio of phytoplankton absorption in blue part $(443 \mathrm{~nm})$ of the spectrum to that in green part $(490 \mathrm{~nm})$ for populations dominated by diatoms (O) and prymnesiophytes (๑). NPC/chl $a=0.396-0.172 a_{\mathrm{ph}}(443) / a_{\mathrm{ph}}(490)$, $\mathrm{n}=28, \mathrm{r}^{2}=0.58$ 
1982, Harrison \& Platt 1986, Tilzer et al. 1986, Figueiras et al. 1994).

The photoadaptive strategy of phytoplankton from the Labrador Sea is thus characterized by an increase in photosynthetic efficiency at lower light levels (higher $\alpha^{\mathrm{B}}$ ) with very little change in $P_{\mathrm{m}}^{\mathrm{B}}$ indicating that phytoplankton at depth utilize the lower irradiance levels more efficiently. This strategy is similar to that seen in Phaeocystis pouchetii advected beneath the ice in McMurdo Sound, Antarctica (Palmisano et al. 1986). Several authors have concluded that, on an annual basis, $P_{\mathrm{m}}^{\mathrm{B}}$ is controlled predominantly by ambient temperature, whereas changes in $\alpha^{\mathrm{B}}$ are controlled by light history (Platt \& Jassby 1976, Harrison \& Platt 1980, 1986). On shorter time scales, however, variations in $P_{\mathrm{m}}^{\mathrm{B}}$ and $\alpha^{\mathrm{B}}$ are related largely to changes in community structure (see Côté \& Platt 1983), as was observed in this study.

The derived photoadaptation parameter, $I_{k}\left(=P_{\mathrm{m}}^{\mathrm{B}} / \alpha^{\mathrm{B}}\right)$, is known to decrease with increasing latitude, and has been shown to be important in the discussion of latitudinal effects on the calculation of primary production (see Platt \& Sathyendranath 1995). Values of $I_{k}$ ranged from 41 to $192 \mu \mathrm{mol}$ quanta $\mathrm{m}^{-2} \mathrm{~s}^{-1}$, with significantly higher values $(p=0.002)$ being recorded for the larger diatoms than for the smaller prymnesiophytes (Table 1).
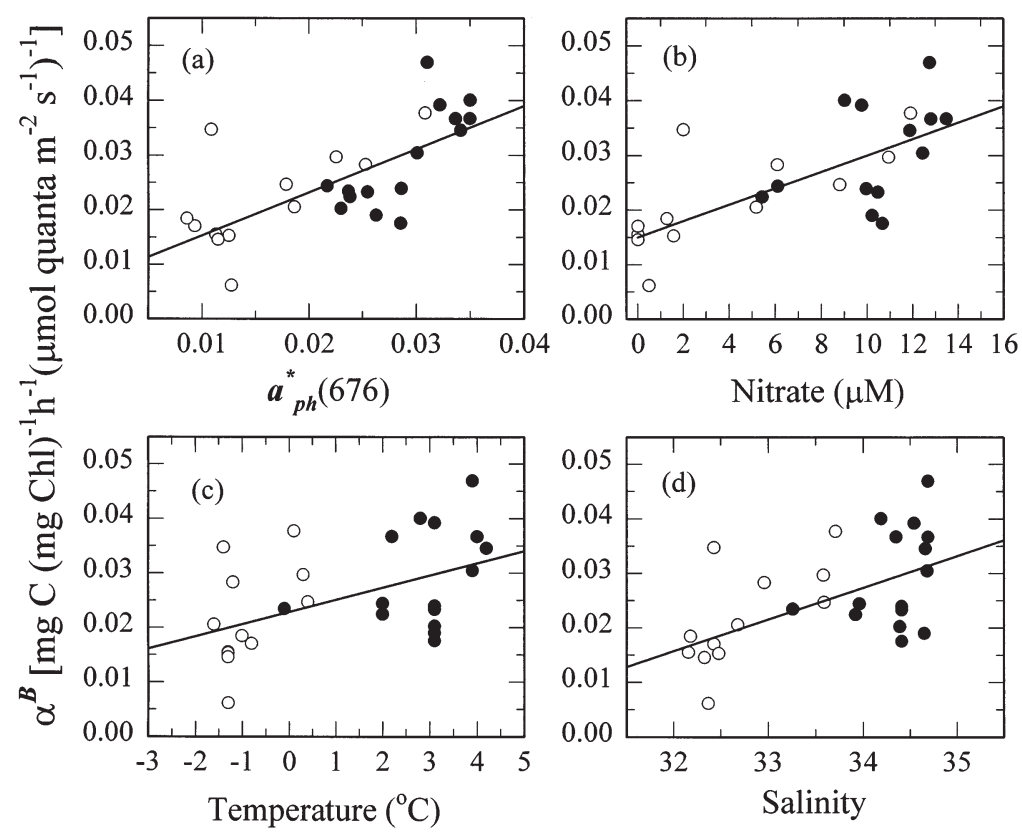

Fig. 9. Initial rate of photosynthesis, $\alpha^{\mathrm{B}}\left(\mathrm{mg} \mathrm{C}[\mathrm{mg} \mathrm{chl}]^{-1} \mathrm{~h}^{-1}\left[\mu \mathrm{mol}\right.\right.$ quanta $\mathrm{m}^{-2}$ $\left.\mathrm{s}^{-1}\right]^{-1}$ ), plotted as a function of (a) specific absorption of phytoplankton at $676 \mathrm{~nm}\left(\mathrm{~m}^{2}[\mathrm{mg} \mathrm{chl} \mathrm{a}]^{-1}\right)\left(\alpha^{\mathrm{B}}=0.00743+0.80087 a_{\mathrm{ph}}^{*}(676), \mathrm{n}=27, \mathrm{r}^{2}=0.50\right)$, (b) nitrate concentration $\left(\alpha^{\mathrm{B}}=0.0155+0.00147 \mathrm{NO}_{3}, \mathrm{n}=25, \mathrm{r}^{2}=0.48\right)$, (c) temperature $\left({ }^{\circ} \mathrm{C}\right)\left(\alpha^{\mathrm{B}}=0.0231+0.00232 T, \mathrm{n}=27, \mathrm{r}^{2}=0.25\right)$, and (d) salinity $(\%)\left(\alpha^{\mathrm{B}}=-0.1727+0.00591 \mathrm{Sal}, \mathrm{n}=27, \mathrm{r}^{2}=0.32\right)$, for phytoplankton populations dominated by diatoms $(\mathrm{O})$ and prymnesiophytes $(\bullet)$
Platt et al. (1993) also noted higher values of $I_{k}$ for the larger size fraction of phytoplankton in the Celtic Sea than for the smaller size fraction and concluded that the daily water-column production would be higher for the smaller size fraction. Similarly, for phytoplankton samples collected in the Arabian Sea, Sathyendranath et al. (1999) found that $I_{k}$ values were slightly lower during the 2 monsoon seasons than during the intermonsoon period; they suggested that this might contribute to the higher water-column production during the monsoon seasons. The differences in $I_{k}$ values between the diatom and prymnesiophyte populations ecorded in the present study may also be interpreted imply faster growth rates and higher rates of primary production for the prymnesiophyte population at a mint intensity. It is interesting to note that Moisan \& Mitchell (1999) recorded relatively high $\phi_{\mathrm{m}}$ (quantum yield for growth) and $a_{\mathrm{ph}}$ values for Phaeopostulated might contribute in part to the ability of $P$. antarctica to initiate blooms in polar regions in early spring, when light levels are low.

Despite the fact that the water column was vertically omogeneous with little evidence of stratification (Fig. 2), $I_{k}$ values decreased with increasing depth (Fig. 10b) presumably as an adaptation to the lower light levels. In addition, $\alpha^{\mathrm{B}}$ also showed some variations with depth $(Z)$ for both the diatom and prymnesiophyte populations, although the data are somewhat limited (Fig. 10a). It is well known that phytoplankton adjust their photosynthetic characteristics to ambient light levels through a number of physiological processes, referred to as photoadaptation (Falkowski 1983, Richardson et al. 1983). These photoadaptive responses may include changes in cellular pigment content or a change in pigment composition, and have often been explained in terms of changes in the number and size of photosynthetic units (Prézelin 1981, Richardson et al. 1983). Many studies have used the photoadaptive response of phytoplankton to estimate the rate or intensity of vertical mixing in near-surface layers (Falkowski 1983, Harrison \& Platt 1986, Cullen \& Lewis 1988). Basically, if the time scale for photoadaptation is shorter than that for vertical mixing, phytoplankton will adjust their metabolic activities in response to ambient light levels, resulting in a nonuniform vertical distribution of P-E parameters. Since our $I_{k}$ values changed markedly with depth, we can conclude that 

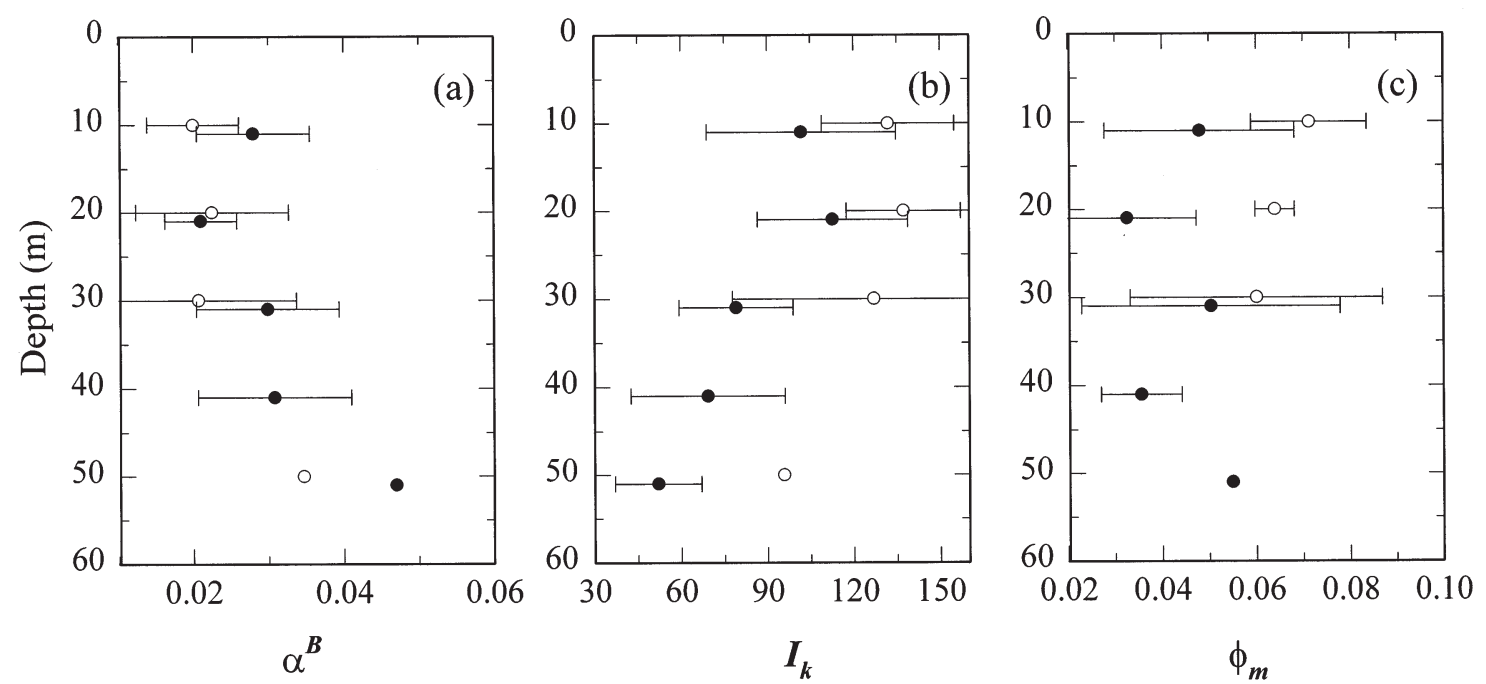

Fig. 10. Variations (means $\pm 1 \mathrm{SD}$ ) in (a) $\alpha^{\mathrm{B}}\left(\mathrm{mg} \mathrm{C}[\mathrm{mg} \mathrm{chl}]^{-1} \mathrm{~h}^{-1}\left[\mu \mathrm{mol} \text { quanta } \mathrm{m}^{-2} \mathrm{~s}^{-1}\right]^{-1}\right)$, (b) $I_{k}\left(\mu \mathrm{mol}\right.$ quanta $\left.\mathrm{m}^{-2} \mathrm{~s}^{-1}\right)$, and $(\mathrm{c}) \phi_{\mathrm{m}}$ $\left(\mathrm{mol} \mathrm{C}[\mathrm{mol} \mathrm{quanta}]^{-1}\right.$ ) with depth for phytoplankton populations dominated by diatoms $(\mathrm{O})$ and prymnesiophytes

phytoplankton were adapting faster than they were mixing.

Because of the limited spatial resolution of P-E data in most areas of the ocean, several authors have attempted to extrapolate a small number of P-E measurements to large scales, for use in computations of primary production from remotely-sensed data (see Sathyendranath \& Platt 1993, Longhurst et al. 1995). In this context it would be desirable to relate photosynthetic parameters to more commonly measured variables that can be detected by remote sensing, e.g. seasurface temperature, which is routinely measured by the NOAA satellites. In this study, $\alpha^{\mathrm{B}}$ was positively related to temperature (Fig. 9c) as well as to other environmental variables, although it is likely that these relationships are indirect and are not universal, and they may also vary regionally and seasonally.

\section{Quantum yield}

The maximum, realized, quantum yield of photosynthesis, $\phi_{\mathrm{m}}$, was estimated from the ratio of $\alpha^{\mathrm{B}}$ to the mean specific-absorption coefficient of phytoplankton (average specific-absorption coefficient over the range 400 to $700 \mathrm{~nm}$ ), scaled by a constant of 0.02315 to convert grams of carbon to moles of carbon and hours to seconds. Values of $\phi_{\mathrm{m}}$ varied from 0.022 to 0.088 mol C (mol quanta) ${ }^{-1}$ with the mean quantum yield for the prymnesiophyte population $(0.044 \mathrm{~mol} \mathrm{C}$ $\left.[\mathrm{mol} \text { quanta }]^{-1}\right)$ being significantly lower $(\mathrm{p}=0.006)$ than that for the diatom population $(0.066 \mathrm{~mol} \mathrm{C}[\mathrm{mol}$ quanta] ${ }^{-1}$ ) (Table 1). Mean values for the prymnesiophyte population were similar to those of phytoplank- ton from the Southern Californian Bight (Schofield et al. 1993) and the Arabian Sea (Sathyendranath et al. 1999). Quantum yield was only weakly related to the proportion of chlorophyll in the $<3 \mu \mathrm{m}$ size fraction (Fig. 11a), but showed a stronger, inverse relationship with the ratio of phytoplankton absorption in the blue to red regions of the spectrum (Fig. 11b), as has been found in other studies. Cleveland et al. (1989) attributed such a decrease in $\phi_{\mathrm{m}}$ to an increased contribution by blue-light-absorbing, non-photosynthetic particles, such as phaeopigments or detritus, whereas Sathyendranath et al. (1996) postulated that changes in phytoplankton population structure and state of photoadaptation governed some of the changes in quantum yield. Indeed, this would appear to be the case here, since the samples tended to be grouped taxonomically.

If phytoplankton absorption spectra can be retrieved by the new generation of hyperspectral ocean-colour sensors, with sufficient precision to distinguish between size-dependent variations in the spectral form, then it may also be possible to monitor variations in quantum yield using remotely-sensed ocean-colour data (see Carder et al. 1995).

The relative proportion of non-photosynthetic carotenoids also appeared to have an influence on the maximum quantum yield of photosynthesis (Fig. 11c). Several authors have noted reduced quantum yields associated with samples containing high levels of photoprotective pigments (Bidigare et al. 1989, Babin et al. 1996). We know that phytoplankton from the middle of the transect contained a relatively greater proportion of the photoprotective pigment diadinoxanthin than did samples from either end of the transect (see Fig. 7). 
Since diadinoxanthin absorbs light but does not transfer energy to Photosystem II (Vernet et al. 1989), it will reduce the quantum yield of photosynthesis, thus accounting for the lower quantum yield in samples with a high proportion of NPCs. It is interesting to note here that samples from the Phaeocystis pouchetii bloom, which contained low levels of NPCs, had higher quantum yields than the other prymnesiophyte samples.

Falkowski (1992) suggested that $\phi_{\mathrm{m}}$ may also be correlated with nutrient availability. Several laboratory studies have shown that nutrient limitation tends to lower quantum yield (Cleveland \& Perry 1987, Sosik \& Mitchell 1991), and field studies have demonstrated a negative correlation between $\phi_{\mathrm{m}}$ and distance from the nitracline (Cleveland et al. 1989, Lizotte \& Priscu 1994). In the present study, there was no distinct nitracline for the range of depths sampled, and $\phi_{\mathrm{m}}$ did not show any relationship with nitrate concentration (Fig. 11d). Furthermore, there was no clear evidence of a depthdependent increase in $\phi_{\mathrm{m}}$ (Fig. 10c), as has been reported in a number of field studies (Babin et al. 1996, Sathyendranath et al. 1996).

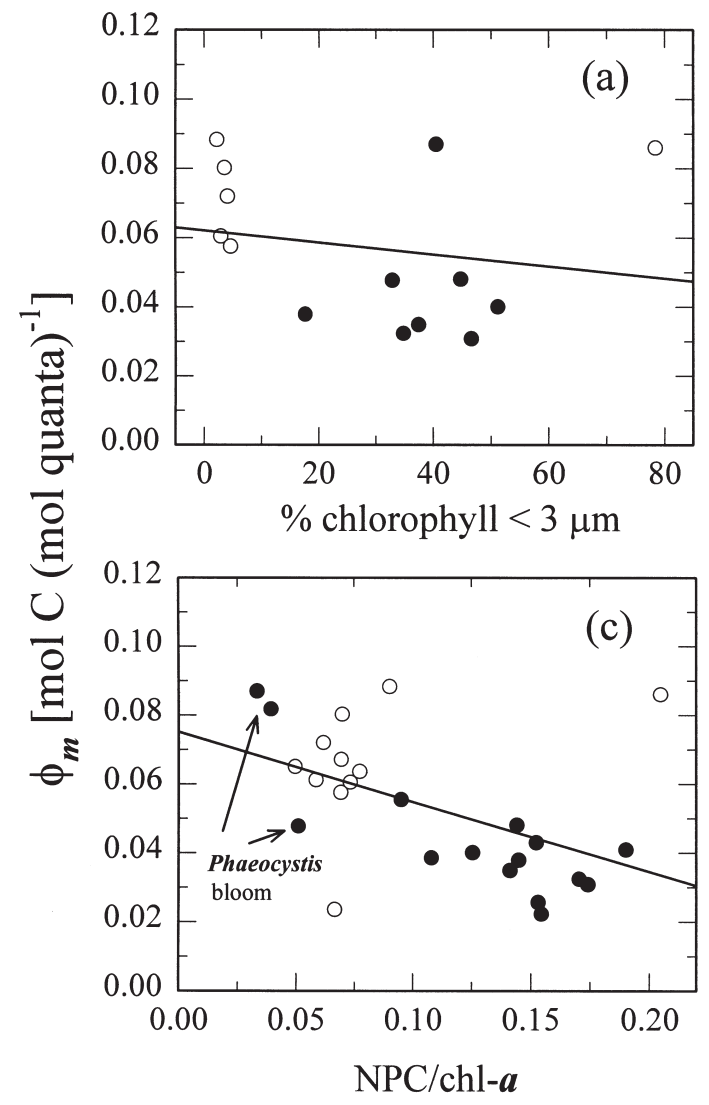

\section{Implications for retrieval of chl a from remotely-sensed data}

Since remote-sensing reflectance varies in response to phytoplankton absorption characteristics, taxonomic differences in phytoplankton absorption can have an impact on the retrieval of chl a from remotely-sensed data. Sathyendranath et al. (2000) developed a theoretical model of ocean colour that relates absorption and backscattering coefficients to reflectance at the sea surface, and examined the impact of variations in phytoplankton absorption properties on the performance of standard remotesensing algorithms. Their model was implemented using phytoplankton absorption data collected from mid- to low-latitude areas, as well as data from the diatom and prymnesiophyte populations in the Labrador Sea obtained from the present study. Their model results suggested that, for the diatom population from the Labrador Sea, the low absorption efficiencies reported here might lead to significant underestimation in retrieved chl a concentrations if
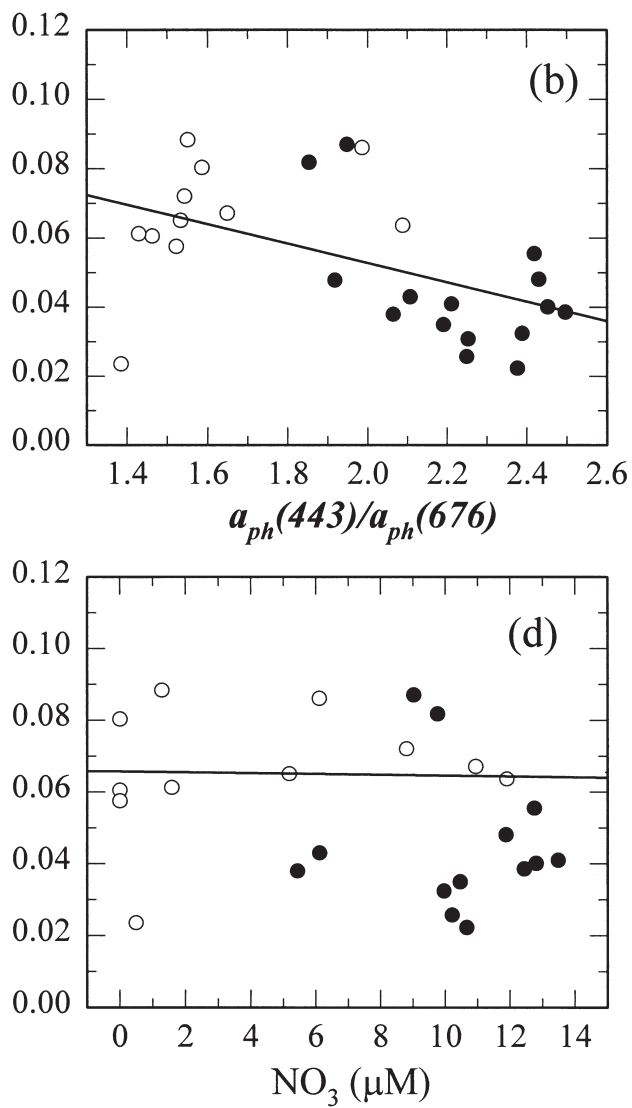

Fig. 11. Relationship between $\phi_{\mathrm{m}}\left(\mathrm{mol} \mathrm{C}[\mathrm{mol} \mathrm{quanta}]^{-1}\right)$ and (a) percentage chlorophyll in $<3 \mu \mathrm{m}$ size-fraction $(F)\left(\phi_{\mathrm{m}}=0.0625-\right.$ $\left.0.000176 F, \mathrm{n}=14, \mathrm{r}^{2}=0.04\right)$; (b) ratio of phytoplankton absorption in blue (443 nm) part of the spectrum to that in the red (676 $\mathrm{nm}$ ) $\left(\phi_{\mathrm{m}}=0.109-0.0282 a_{\mathrm{ph}}(443) / a_{\mathrm{ph}}(676), \mathrm{n}=26, \mathrm{r}^{2}=0.26\right) ;(\mathrm{c})$ the ratio of non-photosynthetic carotenoids to chl $a(R)\left(\phi_{\mathrm{m}}=0.0752-\right.$ $\left.0.203 R, \mathrm{n}=26, \mathrm{r}^{2}=0.25\right)$; (d) concentration of $\mathrm{NO}_{3}\left(\phi_{\mathrm{m}}=0.064-0.00126 \mathrm{NO}_{3}, \mathrm{n}=24, \mathrm{r}^{2}=0.08\right)$. (O, ๑) Phytoplankton populations dominated by diatoms and by prymnesiophytes, respectively 
standard remote-sensing algorithms were used. On the other hand, the prymnesiophyte population from the Labrador Sea showed excellent agreement with the data from lower latitudes, suggesting that the biooptical properties of the prymnesiophyte population were very similar to those of phytoplankton from lower latitudes. Taxonomic differences in the optical properties of phytoplankton assemblages may thus be responsible for some of the variability in the performance of ocean-colour algorithms frequently observed in polar areas.

Other authors have also reported that the standard CZCS algorithm underestimated chlorophyll concentrations in the polar oceans (Müller-Karger et al. 1990, Mitchell 1992, Sullivan et al. 1993), which they attributed to differences in the degree of pigment-packaging between high-latitude phytoplankton species compared with those from temperate waters. Furthermore, Arrigo et al. (1998) noted that the SeaWiFS algorithm underestimated chl a concentrations in the Southern Ocean for stations dominated by cryptophytes, but strongly overestimated chl $a$ in areas dominated by large-celled Phaeocystis antarctica. The overestimate in chl a for the $P$. antarctica population was attributed to the high concentrations of photosynthetic pigment, 19'-hexanoyloxyfucoxanthin, which enhances absorption at $490 \mathrm{~nm}$; this suggests that pigment composition may also influence the retrieval of chl a using standard algorithms.

Several studies have thus concluded that phytoplankton from polar waters have bio-optical properties that differ significantly from those in lower latitudes, and have suggested that different bio-optical algorithms should be used for polar regions (Mitchell \& Holm-Hansen 1991, Mitchell 1992). However, Sathyendranath et al. (2000) observed differences in the performance of algorithms only for diatom populations from high-latitude areas, and not for prymnesiophyte populations, suggesting that the performance of standard algorithms may be compromised only in the presence of certain diatom blooms. As we have seen in this study, bio-optical properties of phytoplankton are not necessarily latitude-dependent, but are more likely to be influenced by the structure of the phytoplankton assemblage and its pigment composition.

It is also apparent that regional algorithms parameterized using bio-optical characteristics of local phytoplankton assemblages would perform better than global algorithms (see Fenton et al. 1994). To account for regional variations in pigment-to-chlorophyll ratios and pigment-packaging effects, Carder et al. (1999) developed semi-analytical algorithms for the MODIS sensor, which were parameterized for 3 different bio-optical domains corresponding to unpackaged, packaged and transitional cases of phytoplankton pigments. This type of approach would help reduce algorithm errors and may lead to a future generation of 'switching algorithms'. However, as pointed out by Carder et al. (1999), misclassification of domains can lead to an increase in errors.

\section{CONCLUDING REMARKS}

In this study, phytoplankton absorption coefficients and the initial slope of the P-E curve $\left(\alpha^{\mathrm{B}}\right)$ were found to be related to cell size and phytoplankton species composition. Small prymnesiophytes had higher specific absorption coefficients and higher initial rates of photosynthesis than large diatoms, and consequently, lower quantum yields. High absorption coefficients of prymnesiophyte populations were attributed to low pigment-packaging effects and, in some cases, to a relatively high proportion of non-photosynthetic pigments. In contrast, the larger diatom cells had relatively low pigment-specific absorption coefficients, caused both by high pigment-packaging effects (large cell size) as well as an increase in intra-cellular chl a concentrations resulting from adaptation to low light levels.

Differences in the bio-optical characteristics of phytoplankton populations can lead to large errors in the retrieval of chl a from remotely-sensed data using standard algorithms, suggesting that species-specific or regional algorithms need to be developed. This would necessitate the retrieval of additional information on particular taxonomic groups from remote-sensing measurements. Such a goal may not be entirely impossible with the new generation of satellite oceancolour sensors, which have a large number of spectral channels (IOCCG 1998). It is unlikely, however, that small-scale differences in species composition, such as were found in the present study, could be resolved easily. Caution should therefore be exercised when retrieving pigment concentrations from high-latitude areas, especially in the case of dense algal blooms comprised of large-celled species such as diatoms.

Acknowledgements. The work presented in this paper was supported, in part, by the Office of Naval Research, USA, the National Aeronautics and Space Administration, USA, and the Department of Fisheries and Oceans, Canada. This work was carried out as part of the Canadian Contribution to the Joint Global Ocean Flux Study (JGOFS). Data were collected during a cruise of the CCGS 'Hudson' to the Labrador Sea: we thank the staff and crew of the ship. Phytoplankton samples were identified and enumerated by Kevin Pauley. 
Appendix 1. Effect of pump on Phaeocystis pouchetii colonies

Extracted chlorophyll concentrations and specific-absorption data for 2 sets of samples collected from Phaeocystis pouchetii bloom in Labrador Sea in May 1997 are shown in Table A1. Samples were collected by bucket as well as sampling pump. Results indicate that sampling pump did not cause cellular damage to the $P$. pouchetii cells, since chlorophyll values for both methods of collection are similar (Table A1). Furthermore, disruption of colonies by the pump had little effect on the absorption properties of the $P$. pouchetii-dominated colonies, since both methods of collection yielded similar values for $a_{\mathrm{ph}}^{*}(440)$ (Table A1)
Table A1. Extracted chlorophyll concentration $\left(\mathrm{mg} \mathrm{m}^{-3}\right)$ and specific absorption coefficients at $440 \mathrm{~nm}\left(\mathrm{~m}^{2}\left[\mathrm{mg} \mathrm{chl} \mathrm{a}^{-1}\right)\right.$ for 2 samples collected from Phaeocystis pouchetii bloom using sampling pump and bucket. Samples collected in May 1997 during cruise to the Labrador Sea

\begin{tabular}{lcccc}
$\begin{array}{l}\text { Sampling } \\
\text { method }\end{array}$ & $\begin{array}{c}\text { Sample 1 } \\
\text { chl }\end{array}$ & $\begin{array}{c}\text { Sample 2 } \\
\text { chl }\end{array}$ & $\begin{array}{c}\text { Sample 1 } \\
a_{\mathrm{ph}}^{*}(440)\end{array}$ & $\begin{array}{c}\text { Sample 2 } \\
\mathrm{a}_{\mathrm{ph}}^{*}(440)\end{array}$ \\
\hline Pump & 5.52 & 4.54 & 0.054 & 0.059 \\
Bucket & 4.95 & 4.37 & 0.049 & 0.057 \\
\hline
\end{tabular}

\section{LITERATURE CITED}

Arrigo KR, Robinson DH, Sullivan CW (1993) A high resolution study of the platelet ice ecosystem in McMurdo Sound, Antarctica: photosynthetic and bio-optical characteristics of a dense microalgal bloom. Mar Ecol Prog Ser 98:173-185

Arrigo KR, Robinson DH, Worthen DL, Schieber B, Lizotte MP (1998) Bio-optical properties of the southwestern Ross Sea. J Geophys Res 103:21683-21695

Babin M, Morel A, Claustre H, Bricaud A, Kolber Z, Falkowski PG (1996) Nitrogen- and irradiance-dependent variations of the maximum quantum yield of carbon fixation in eutrophic, mesotrophic and oligotrophic marine systems. Deep-Sea Res 43:1241-1272

Bidigare RR, Schofield O, Prézelin BB (1989) Influence of zeaxanthin on quantum yield of photosynthesis of Synechococcus clone WH7803 (DC2). Mar Ecol Prog Ser 56:177-188

Bricaud A, Stramski D (1990) Spectral absorption coefficients of living phytoplankton and nonalgal biogenous matter: a comparison between the Peru upwelling area and the Sargasso Sea. Limnol Oceanogr 35:562-582

Bricaud A, Babin M, Morel A, Claustre H (1995) Variability in the chlorophyll-specific absorption coefficients of natural phytoplankton: analysis and parameterization. J Geophys Res 100:13321-13332

Buma AGJ, Bano N, Veldhuis MJW, Kraay GW (1991) Comparison of the pigmentation of two strains of the prymnesiophyte Phaeocystis sp. Neth J Sea Res 27:173-182

Cabal J, Harris LR, Head EJH (1997) Egg production rates of Calanus finmarchicus in the Northwest Atlantic (Labrador Sea). Can J Fish Aquat Sci 54:1270-1279

Carder KL, Lee ZP, Marra J, Steward RG, Perry MJ (1995) Calculated quantum yield of photosynthesis of phytoplankton in the marine light-mixed layers $\left(59^{\circ} \mathrm{N}, 21^{\circ} \mathrm{W}\right)$. J Geophys Res 100:6655-6663

Carder KL, Chen FR, Lee ZP, Hawes SK, Kamykowski D (1999) Semianalytic moderate-resolution imaging spectrometer algorithms for chlorophyll $a$ and absorption with bio-optical domains based on nitrate-depletion temperatures. J Geophys Res 104:5403-5421

Cleveland JS, Perry MJ (1987) Quantum yield, relative specific absorption and fluorescence in nitrogen-limited Chaetoceros gracilis. Mar Biol 94:489-497

Cleveland JS, Perry MJ, Kiefer DA, Talbot MC (1989) Maximal quantum yield of photosynthesis in the northwestern Sargasso Sea. J Mar Res 47:869-886

Cota GA, Smith WO, Mitchell BG (1994) Photosynthesis of Phaeocystis in the Greenland Sea. Limnol Oceanogr 39: 948-953
Côté B, Platt T (1983) Day-to-day variations in the springsummer photosynthetic parameters of coastal marine phytoplankton. Limnol Oceanogr 28:320-344

Cullen JJ, Lewis MR (1988) The kinetics of algal photoadaptation in the context of vertical mixing. J Plankton Res 10: 1039-1063

Culver ME, Perry MJ (1999) The response of photosynthetic absorption coefficients to irradiance in culture and in tidally mixed estuarine waters. Limnol Oceanogr 44:24-36

Duysens LNM (1956) The flattening of the absorption spectrum of suspensions, as compared to that of solutions. Biochim Biophys Acta 19:1-12

Falkowski PG (1983) Light-shade adaptation and vertical mixing of marine phytoplankton: a comparative field study. J Mar Res 41:215-237

Falkowski PG (1992) Molecular ecology of phytoplankton photosynthesis. In: Falkowski PG, Woodhead AD (eds) Primary productivity and biogeochemical cycles in the sea. Plenum Press, New York, p 47-67

Fenton N, Priddle J, Tett P (1994) Regional variations in biooptical properties of the surface waters in the Southern Ocean. Antarct Sci 6:443-448

Figueiras FG, Pérez FF, Pazos Y, Rios AF (1994) Light and productivity of Antarctic phytoplankton during austral summer in an ice edge region in the Weddell-Scotia Sea. J Plankton Res 16:233-253

Geider RJ, Osborne BA (1987) Light absorption by a marine diatom: experimental observations and theoretical calculations of the package effect in a small Thalassiosira species. Mar Biol 96:299-308

Harrison WG, Platt T (1980) Variations in assimilation number of coastal marine phytoplankton: effects of environmental co-variates. J Plankton Res 2:249-260

Harrison WG, Platt T (1986) Photosynthesis-irradiance relationships in polar and temperate phytoplankton populations. Polar Biol 5:153-164

Head EJH, Horne EPW (1993) Pigment transformation and vertical flux in an area of convergence in the North Atlantic. Deep-Sea Res 40:329-346

Head EJH, Harris LR, Campbell RW (2000) Investigations on the ecology of Calanus spp. in the Labrador Sea. I. Relationship between the phytoplankton bloom and reproduction and development of Calanus finmarchicus in spring. Mar Ecol Prog Ser 193:53-73

Hoepffner N, Sathyendranath S (1992) Bio-optical characteristics of coastal waters: absorption spectra of phytoplankton and pigment distribution in the western North Atlantic. Limnol Oceanogr 37:1660-1679

Hoepffner N, Sathyendranath S (1993) Determination of the major groups of phytoplankton pigments from the absorp- 
tion spectra of total particulate matter. J Geophys Res 98: 22789-22803

Holm-Hansen O, Lorenzen CJ, Holmes RW, Strickland JDH (1965) Fluorometric determination of chlorophyll. J Cons Perm Int Explor Mer 30:3-15

IOCCG (1998) Minimum requirements for an operational ocean-colour sensor for the open ocean. International Ocean Colour Coordinating Group, Dartmouth, Canada (Rep No. 1, IOCCG)

Irwin B, Anning J, Caverhill C, Platt T (1990) Primary production on the Labrador Shelf and in the Strait of Belle Isle in May 1988. Can Data Rep Fish Aquat Sci 784

Jeffrey SW, Mantoura RFC, Wright SW (1997) Phytoplankton pigments in oceanography. UNESCO, Paris

Johnsen G, Sakshaug E (1993) Bio-optical characteristics and photoadaptive responses in the toxic and bloom-forming dinoflagellates Gyrodinium aureolum, Gymnodinium galatheanum, and two strains of Prorocentrum minimum. J Phycol 29:627-642

Johnsen G, Sakshaug E (1996) Light harvesting in bloomforming marine phytoplankton: species-specificity and photoacclimation. Sci Mar 60:47-56

Joint IR, Pomroy AJ (1986) Photosynthetic characteristics of nanoplankton and picoplankton from the surface mixed layer. Mar Biol 92:465-474

Kirk JTO (1994) Light and photosynthesis in aquatic ecosystems. Cambridge University Press, Cambridge

Kishino M, Takahashi M, Okami N, Ichimura S (1985) Estimation of the spectral absorption coefficients of phytoplankton in the sea. Bull Mar Sci 37:634-642

Kyewalyanga MN, Platt T, Sathyendranath S (1997) Estimation of the photosynthetic action spectrum: implications for primary production models. Mar Ecol Prog Ser 146: 207-223

Lizotte MP, Priscu JC (1994) Natural fluorescence and quantum yield in vertical stationary phytoplankton from perennially ice-covered lakes. Limnol Oceanogr 39:1399-1410

Longhurst A, Sathyendranath S, Platt T, Caverhill C (1995) An estimate of global primary production in the ocean from satellite radiometer data. J Plankton Res 17:1245-1271

Lutz VA, Sathyendranath S, Head EJH (1996) Absorption coefficient of phytoplankton: regional variations in the North Atlantic. Mar Ecol Prog Ser 135:197-213

Mitchell BG (1992) Predictive bio-optical relationships for polar oceans and marginal ice zones. J Mar Syst 3:91-105

Mitchell BG, Holm-Hansen O (1991) Bio-optical properties of Antarctic Peninsula waters: differentiation from temperate ocean models. Deep-Sea Res 38:1009-1028

Mitchell BG, Kiefer DA (1984) Determination of absorption and fluorescence excitation spectra for phytoplankton. In: Holm-Hansen O, Bolis L, Giles R (eds) Marine phytoplankton and productivity. Springer-Verlag, Berlin, p 157-169

Mitchell BG, Kiefer DA (1988) Variability in pigment specific particulate fluorescence and absorption spectra in the northeastern Pacific Ocean. Deep-Sea Res 35:665-689

Moisan TA, Mitchell BG (1999) Photophysiological acclimation of Phaeocystis antarctica Karsten under light limitation. Limnol Oceanogr 44:247-258

Morel A, Bricaud A (1981) Theoretical results concerning light absorption in a discrete medium, and application to specific absorption of phytoplankton. Deep-Sea Res 28A: 1375-1393

Morel A, Prieur L (1977) Analysis of variations in ocean color. Limnol Oceanogr 22:709-722

Müller-Karger FE, McClain CR, Sambrotto RN, Ray GC (1990) A comparison of ship and coastal zone color scan- ner mapped distribution of phytoplankton in the southeastern Bering Sea. J Geophys Res 95:11483-11499

Neori A, Holm-Hansen O (1982) Effects of temperature on rates of photosynthesis in Antarctic phytoplankton. Polar Biol 1:33-38

O'Reilly JE, Maritorena S, Mitchell BG, Siegel DA, Carder KL, Garver SA, Kahru M, McClain C (1998) Ocean color chlorophyll algorithms for SeaWiFS. J Geophys Res 103: 24937-24953

Palmisano AC, SooHoo JB, SooHoo SL, Kottmeier ST, Craft LL, Sullivan CW (1986) Photoadaptation of Phaeocystis pouchetii advected beneath annual sea ice in McMurdo Sound, Antarctica. J Plankton Res 8:891-906

Platt T, Jassby AD (1976) The relationship between photosynthesis and light for natural assemblages of coastal marine phytoplankton. J Phycol 12:421-430

Platt T, Sathyendranath S (1995) Latitude as a factor in the calculation of primary production. In: Skjoldal HR, Hopkins C, Erikstad KE, Leinaas HP (eds) Ecology of fjords and coastal waters. Elsevier Science, Amsterdam, p 3-13

Platt T, Gallegos CL, Harrison WG (1980) Photoinhibition of photosynthesis in natural assemblages of marine phytoplankton. J Mar Res 38:687-701

Platt T, Subba Rao DV, Irwin B (1983) Photosynthesis of picoplankton in the oligotrophic ocean. Nature 300:702-704

Platt T, Sathyendranath S, Joint I, Fasham MJR (1993) Photosynthesis characteristics of the phytoplankton in the Celtic Sea during late spring. Fish Oceanogr 2:191-201

Prézelin BB (1981) Light reactions in photosynthesis. Can J Fish Aquat Sci 210:1-43

Richardson K, Beardall J, Raven JA (1983) Adaptation of unicellular algae to irradiance: an analysis of strategies. New Phytol 93:157-191

Robinson DH (1992) Photosynthesis in sea ice microalgae: response to low temperatures and extremes of irradiance. PhD dissertation. University of Southern California, Los Angeles

Sakshaug E, Slagstad D (1991) Light and productivity of phytoplankton in polar marine ecosystems: a physiological view. Polar Res 10:69-85

Sathyendranath S, Platt T (1993) Remote sensing of water-column primary production. In: Li WKW, Maestrini SY (eds) Measurement of primary production from the molecular to the global scale. ICES Mar Sci Symp 197:236-243

Sathyendranath S, Platt T, Stuart V, Irwin BD, Veldhuis MJW, Kraay GW, Harrison WG (1996) Some bio-optical characteristics of phytoplankton in the N.W. Indian Ocean. Mar Ecol Prog Ser 132:299-311

Sathyendranath S, Stuart V, Irwin BD, Maass H, Savidge G, Gilpin L, Platt T (1999) Seasonal variations in bio-optical properties of phytoplankton in the Arabian Sea. Deep-Sea Res 46:633-654

Sathyendranath S, Stuart V, Cota G, Maass H, Platt T (2000) Remote sensing of phytoplankton pigments: a comparison of empirical and theoretical approaches. Int J Remote Sensing (in press)

Schofield O, Prézelin BB, Bidigare RR, Smith RC (1993) In situ photosynthetic quantum yield. Correspondence to hydrographic and optical variability within the Southern California Bight. Mar Ecol Prog Ser 93:25-37

Sosik HM, Mitchell BG (1991) Absorption, fluorescence, and quantum yield for growth in nitrogen-limited Dunaliella tertiolecta. Limnol Oceanogr 36:910-921

Stuart V, Sathyendranath S, Platt T, Maass H, Irwin BD (1998) Pigments and species composition of natural phytoplankton populations: effect on the absorption spectra. J Plankton Res 20:187-217 
Sullivan CW, Arrigo KR, McClain CR, Comiso JC, Firestone J (1993) Distributions of phytoplankton blooms in the Southern Ocean. Science 262:1832-1837

Tilzer MM, Elbrächter M，Gieskes WW， Beese B (1986) Light-temperature interactions in the control of photosynthesis in Antarctic phytoplankton. Polar Biol 5:105-111

Editorial responsibility: Otto Kinne (Editor), Oldendorf/Luhe, Germany
Vernet M, Neori A, Haxo FT (1989) Spectral properties and photosynthetic action in red-tide populations of Prorocentrum micans and Gonyaulax polyedra. Mar Biol 193:365-371

Yentsch CS (1962) Measurement of visible light absorption by particulate matter in the ocean. Limnol Oceanogr 7: $207-217$

Submitted: August 17, 1999; Accepted: January 7, 2000 Proofs received from author(s): July 11, 2000 